\title{
Wartościowanie motywu 'Ojczyzny' i 'Synczyzny' w Trans-Atlantyku Witolda Gombrowicza w świetle metodologii semantyki interpretacyjnej
}

Słowa klucze: izotopia semantyczna; wartościowanie; interpretacja; tekst

Ke y w or d s : semantic isotopy; valuation; interpretation; text

\section{Uwagi wstępne}

Problematyka aksjologicznego nacechowania treści semantycznych w języku i dyskursie, szeroko opisana w literaturze językoznawczej¹, narzuca się nieodzownie w analizie niemal każdego tekstu o charakterze nieutylitarnym (literackiego, dziennikarskiego, filozoficznego itp.) z uwagi na istotną - a niejednokrotnie wręcz centralną - rolę wartościującego składnika znaczenia. Analiza ta musi objąć nie tylko normatywne (,słownikowe”) nacechowanie danego leksemu, ale również wszelkie czynniki wpływające na

${ }^{1}$ Zob. m.in. z badań polskich (sytuujących się w innej perspektywie badawczej niż ta, którą przyjmujemy w niniejszym artykule) : Puzynina (1992), Laskowska (1992), Bartmiński (2003) ; z badań francuskojęzycznych : Galatanu (2007), Rezsohazy (2006), Carlos et Pérennec (2012), Charaudeau et Maingueneau (2012), numer 184 Langue française (2014), Krzyżanowska i Wołowska (2016 a i b). 
aktualizację wartościujących elementów sensu (często bardzo subtelnych i zmiennych) w szeroko pojętym kontekście².

Badania językoznawcze dotyczące zarówno procesu wypowiadania, jak i struktury znaczenia budowanego w obrębie tekstu opisują szczegółowo wszelkie wykładniki subiektywności, w tym ocen aksjologicznych i postaw, jakie podmiot wypowiadający przyjmuje wobec wypowiadanej treści (zob. zwłaszcza Benveniste 1966, Kerbrat-Orecchioni 1980). Wymiar ten

odnosi się do wszelkich operacji i znaczników służących podmiotowi wypowiadającemu do wyrażania ocen i osądów typu dobry / zły (pożądany / niepożądany...) lub reakcji emocjonalnych naznaczonych tego typu osądem (Jackiewicz 2014: 5).

Z uwagi na owo silne powiązanie $\mathrm{z}$ wymiarem e mocjonalny ${ }^{3}$ wartościujący komponent znaczenia stanowi atrakcyjny punkt odniesienia dla różnego rodzaju stylistycznych zabiegów językowych, w skrajnym przypadku grających na całkowitym zaprzeczeniu lub odwróceniu ogólnie przyjętych dla danej treści wartości, w szczególności w przypadku tekstów o mocno zaznaczonej funkcji estetycznej. Niniejszy artykuł jest poświęcony analizie takiego właśnie zabiegu, mianowicie sprzecznego wartościowania treści semantycznych związanych z kategoriami 'Ojca' i 'Syna' w Trans-Atlantyku Witolda Gombrowicza ${ }^{4}$.

O wartościowaniu sprzecznym można mówić w przypadku, gdy znaczenie leksemu pozytywnie nacechowanie w języku nabiera w kontekście wartości negatywnej lub odwrotnie. Mechanizm ten przebadam z punktu widzenia interpretacyjnego (tj. biorącego pod uwagę perspektywę odbiorcy) przy użyciu metodologii semantyki składnikowej dostosowanej do analizy struktury znaczenia w tekście (głównym punktem odniesienia będzie tu

2 Obejmującym kotekst (najbliższe otoczenie analizowanego elementu), tekst (postrzegany jako całość semantyczna, której integralną częścią jest badany element), intertekst, jak również kontekst gatunkowy, a nawet relewantne aspekty kontekstu pozajęzykowego.

${ }^{3}$ Kwestii emocji w języku również zostały poświęcone liczne prace językoznawcze, m.in. Novakova i Tutin (2009), Plantin (2011), Krzyżanowska (2011), Blumenthal, Novakova i Siepmann (2014), Novakova i Sorba (2014), Krzyżanowska i Wołowska (op.cit.).

4 Temat ten został szerzej rozwinięty w Wołowska 2016; problematyce izotopii wartościujących poświęcony został także artykuł Wołowska 2017. 
francuska semantyka interpretacyjna F. Rastiera). W tej optyce szczególnie istotne jest określenie przynależności badanych elementów do odpowiednich izotopii wartościujących odpowiedzialnych za aksjologiczne nacechowanie kluczowych pojęć organizujących tekst Trans-Atlantyku, do których niewątpliwie należy opozycja Ojciec / Syn (Ojczyzna / Synczyzna).

\section{Izotopia wartościująca - definicja i metoda analizy}

Pojęcie izotopi semantycznej, wprowadzone przez A. J. Greimasa (zob. 1966) i eksploatowane szczególnie intensywnie w badaniach językoznawczych w latach 1970-805, jest związane z problematyką spójności tekstu, a także jego progresji tematycznej i strategii jego interpretacji. Według definicji zaproponowanej przez F. Rastiera (1987), analizującego spójność tekstu przez pryzmat mikrostruktury semicznej użytych w nim jednostek leksykalnych, czyli s e m e mó w, izotopia jest „powtórzeniem semu na osi syntagmatycznej dyskursu" (ibid., 91, 110), które buduje relację spójności semantycznej między sememami zawierającymi ten sem (sem izotopujący, fr. sème isotopant). W teorii Rastiera typologia izotopii opiera się na typologii semów, w szczególności na rozróżnieniu między semami g e n e r y c z n y mi i specyficznymi. Semy generyczne wskazują na przynależność danego sememu do odpowiedniej klasy semantycznej (np. 'kobieta' i 'mężczyzna' posiadają wspólny sem generyczny /człowiek/), zaś semy specyficzne odróżniają od siebie sememy w ramach jednej klasy semantycznej (czyli w przypadku 'kobieta' i mężczyzna' są to semy /męski/ i /żeński/). Powtórzenie semu danego typu na planie syntagmatycznym tworzy odpowiednią izotopię, generyczną lub specyficzną, przy czym izotopie specyficzne mają najczęściej charakter lokalny, natomiast największe znaczenie dla spójności tematycznej tekstu mają izotopie generyczne. Ich typologia odzwierciedla typologię semów generycznych; wyróżniamy zatem izotopie:

1. mikrogeneryczną (powtórzenie semu mikrogenerycznego wskazującego na przynależność sememu do minimalnej klasy semantycznej zwanej t a k s e me m (np. /owoc/ dla 'jabłko', 'truskawka', 'jagoda', 'pomarańcza' itp.);

5 Zob. m.in. Arrivé (1973), Pottier (1974), Berrendonner (1976), Kerbrat-Orecchioni (1976, 1979), Rastier (1985, 1987), Groupe $\mu$ (1990); z nowszych badań zob. np. Cusimano (2015). 
2. mezogeneryczną związaną z powtórzeniem semu mezogenerycznego wpisującego dany semem w d o m e n ę semantyczną (np. dla sememu 'jabłko' będzie to, w zależności od kontekstu, domena //roślinny// albo //jadalny//);

3. makrogeneryczną wynikającą z powtórzenia semu makrogenerycznego, który zaznacza przynależność sememu do w y m i a r u semantycznego czyli kategorii o najwyższym stopniu ogólności (w przypadku sememu 'jabłko' jest to domena //nieożywiony//). Wymiary semantyczne są nieliczne i opierają się na najbardziej ogólnych opozycjach, mianowicie /ożywiony/ vs /nieożywiony/, /konkretny/ vs /abstrakcyjny/, a także /pozytywny/ vs /negatywny/ - w tym ostatnim przypadku mamy do czynienia z izotopią wa r to śc i ują c ą .

Należy tu wspomnieć również o drugim rozróżnieniu typologicznym semów, które ma istotne znaczenie dla analizy mikrostruktury znaczenia, mianowicie o podziale na semy in h e r e n t ne, czyli względnie stałe komponenty sememu (jak /męski/ w sememie 'mężczyzna'), oraz semy a fe rentne, które aktualizują się pod wpływem kontekstu (np. /silny/ i/lub /odważny/ w sememie 'mężczyzna' użytym w przykładowym kontekście: „Zachowaj się jak mężczyzna!”). Z punktu widzenia typologii izotopii jest to jednak rozróżnienie o mniejszym znaczeniu, gdyż rzadko się zdarza, by izotopia składała się wyłącznie z semów inherentnych lub aferentnych - najczęściej sem izotopujący w jednych sememach występuje jako inherentny, w innych aktualizuje się w wyniku aferencji kontekstowej.

Izotopie mogą się konstytuować na różnych poziomach kontekstu, począwszy od dwuczłonowej syntagmy, która jest kontekstem minimalnym (dwa sememy posiadające przynajmniej jeden wspólny sem), przez wypowiedzenie odpowiadające gramatycznej strukturze zdania, sekwencję tekstu, pełny tekst, aż po całe korpusy tekstów, np. dzieła jednego autora czy teksty reprezentujące dany typ dyskursu (jak dyskurs polityczny, religijny, prawniczy itp.). Choć rozpoznanie izotopii semantycznej w trakcie interpretacji linearnej tekstu opiera się przede wszystkim na analizie znaczenia jednostek leksykalnych i jego ewentualnych modyfikacji w kontekście, ma ono również wpływ na interpretację dalszych partii tekstu lub powiązań intertekstowych na mocy tzw. hip otezy interpretacyjnej (fr. presomption d'isotopie, zob. Rastier 1985, 34). Jest to intuicyjna strategia odbiorcy polegająca na założeniu, że w dalszej części tekstu będą kontynuowane izoto- 
pie już wcześniej potwierdzone, co pozwala a priori dość precyzyjnie ukierunkować interpretację. Na przykład, jeśli w wypowiedzeniu Na obiad byt schabowy z ziemniakami semem izotopującym jest sem mezogeneryczny /jedzenie/, w następującym po nim wypowiedzeniu To klasyka gatunku odbiorca automatycznie założy, że izotopia /jedzenie/ jest kontynuowana, czyli że nie chodzi tu np. o klasyczną modę czy muzykę, a o żartobliwe określenie wspomnianego typowego dania. Naturalnie w każdej chwili kontekst może taką hipotezę interpretacyjną obalić, jednak zazwyczaj działa ona bardzo efektywnie, gdyż opiera się na prymarnym założeniu spójności semantycznej tekstu.

\section{Izotopia wartościująca a normatywne nacechowanie leksemu}

Badania nad wartościowaniem znaczenia wpisujące się w optykę analizy tekstu dążą zazwyczaj do opisu korelacji, jaka występuje pomiędzy leksemami a elementami z wyższych poziomów analizy (tekstu, intertekstu, czynników gatunkowych itd., zob. np. Legallois i Lenepveu 2014, Novakova i Sorba 2014, Wołowska 2017). Jak wspomniałam powyżej, analiza wartościowania motywów 'Ojca' i 'Syna' w Trans-Atlantyku skupi się na sposobie ich konstruowania na planie syntagmatycznym tekstu poprzez przypisanie odpowiadających im sememów do izotopii wartościującej z poziomu makrogenerycznego. Przynależność sememu do danej semantycznej kategorii kontekstowej (//pozytywny// lub //negatywny//) zależy przede wszystkim od decydującego w tym względzie czynnika k o n te k s tow e g o; niemniej pełna analiza wartościowania badanej jednostki obejmuje również wpływ czynnika n o r matywnego, który determinuje nacechowanie wartościujące leksemu poza kontekstem w oparciu o jego typowe użycia (s e m e m - t y p ${ }^{6}$ ).

${ }^{6} \mathrm{~S}$ e m e m-ty p (fr. sémème-type) to względnie stała konfiguracja semów inherentnych potwierdzona poprzez użycie leksemu w kontekstach typowych i skodyfikowana w definicjach słownikowych, jego kontekstowym odpowiednikiem jest natomiast s e m e m-uży c i e (fr. sémème-occurrence), czyli unikalna struktura semiczna, która może pokrywać się ze strukturą sememu-typu, ale może ją również modyfikować w bardzo znaczący sposób poprzez neutralizację niektórych semów inherentnych i/lub aktualizację dodatkowych semów aferentnych (zob. Rastier 1987: 83). Np. semem-typ 'fotel' zawiera semy inherentne /mebel/, /do siedzenia/, /miękki/, /z oparciem/, /jednoosobowy/. Jednak w kontekście wypowiedzenia Piotr zasiadt $w$ fotelu prezesa semem-użycie 'fotel' 
Wartościowanie może być przypisane leksemowi explicite na mocy ogólnie przyjętej opinii (konwencji społecznej) i w konsekwencji wprowadzone do słownika jako inherentny (definicyjny) element jego znaczenia; np. 'nieszczęście' (<zdarzenie przynoszące stratę, ból, problemy, cierpienie itp.; niedola, tragedia $>$, SJP) zawiera semy /dysforyczny/, /niepożądany/, /negatywny/, które determinują jego negatywne nacechowanie w języku. W innych przypadkach normatywne nacechowanie znaczenia leksemu albo może zostać wyprowadzone poprzez inferencję $\mathrm{z}$ analizy typowego wartościowania jego innych elementów; np. semem-typ 'rodzina' („małżonkowie i ich dzieci; ogólniej też: osoby związane pokrewieństwem i powinowactwem”, ibid.), pozornie neutralny z punktu widzenia aksjologicznego, nabiera wartości pozytywnej w obliczu przykładów swego typowego użycia (zob. np. slogan Rodzina jest najważniejsza czy tytuły prasowe typu Marzenie facetów? Założenie rodziny ${ }^{7}$ ). Jednakże duża część słownictwa każdego języka pozostaje neutralna (czyli nie jest nacechowana ani aksjologicznie, ani emocjonalnie), co sprawia, że jedynie kontekst może przypisać takim jednostkom jakikolwiek wartościujący aspekt znaczenia. Biorąc pod uwagę kontekst i przyjętą hipotezę interpretacyjną, odbiorca rewiduje dane zawarte w znaczeniu leksykalnym sememu-typu i przypisuje sememowi-użyciu takie nacechowanie wartościujące, jakie wynika z przeprowadzonych przez niego operacji interpretacyjnych (takich jak wirtualizacja niektórych semów inherentnych i aktualizacja w to miejsce innych - często przeciwnych - semów kontekstowych). W ten sposób normatywne nacechowanie leksemu może zostać potwierdzone, niepotwierdzone lub całkowicie zaprzeczone w kontekście, przy czym oczywiście ten ostatni przypadek - występujący również w badanej powieści Gombrowicza - odpowiada za najciekawsze efekty semantyczno-stylistyczne w tekście literackim.

traci większość semów inherentnych (z wyjątkiem semu /jednoosobowy/), nabywa za to pod wpływem kontekstu kluczowy sem aferentny /władza/.

7 http://facet.dlastudenta.pl/artykul/Marzenie_facetow_Zalozenie_rodziny,24467.html 


\section{Motyw 'Ojczyzny' i 'Synczyzny' w Trans-Atlantyku - wartościo- wanie normatywne i kontekstowe}

Znana jest historia Trans-Atlantyku, a zwłaszcza jego chłodnego przyjęcia w Polsce, gdzie trudna w swej warstwie językowej, a do tego zawierająca satyryczną wizję społeczności polskiej w Argentynie powieść wzbudziła niechęć, a nawet oburzenie jako ,atak na święty patriotyzm” (Jelenski 1976: 7) i dowód na moralną zdradę przebywającego na emigracji pisarza. Tymczasem według jego własnych słów, Trans-Atlantyk to „tylko opowiadanie, to nic więcej jak tylko pewien świat opowiedziany - który o tyle może być coś wart, o ile okaże się ucieszny, barwny, odkrywczy i pobudzający - to coś lśniącego i migotliwego, mieniącego się mnóstwem znaczeń" (Gombrowicz 1988b: 7). Z punktu widzenia językoznawczego, pewne elementy kontekstu pozajęzykowego (sytuacja polityczna w Polsce i Europie, czyli wybuch II wojny światowej, która zmusiła Gombrowicza do spędzenia wielu lat na emigracji w Ameryce Południowej), jak i intertekstowego (szczególnie fascynacja motywem n i ed oj r z ało śc i, który pojawia się już w najwcześniejszych utworach autora - Pamiętniku z okresu dojrzewania i Ferdydurke), muszą być wzięte pod uwagę jako relewantne dla uchwycenia pełnego znaczenia wykreowanego w tekście. Nie należy przy tym zapominać, że mamy do czynienia z tekstem literackim, fikcyjnym, stanowiącym pewną całość semantyczną, ale i artystyczną - jako taki należy go więc analizować również w aspekcie jego nacechowania wartościującego i emocjonalnego.

Jedną z głównych osi semantyczno-kompozycyjnych Trans-Atlantyku jest opozycja (sytuująca się na planie mezogenerycznym) między dwiema niekompatybilnymi acz przenikającymi się nawzajem rzeczywistościami z jednej strony światem Ojczyzny, związanym ze wszystkim, co dotyczy Ojca (starego Tomasza), jak i patriotyczną postawą względem kraju pochodzenia (historii i tradycji narodu, wierności minionym ideałom), a z drugiej strony światem Synczyzny, odnoszącej się do Syna (Ignacego, jedynego syna Tomasza) oraz do młodości, świeżości, wolności od wszelkiego bagażu przeszłości i kreatywności właściwej młodemu pokoleniu. Z punktu widzenia leksykalnego jednostki ojciec i syn - rozpatrywane poza wszelkim kontekstem - nie są explicite nacechowane aksjologicznie, jednak mogą zostać naznaczone konkretną wartością, gdy tylko wejdą w odpowiednią klasę kontekstową (funkcjonującą jako ich normatywny „kontekst paradyg- 
matyczny"8). Tak też dzieje się w przypadku sememów 'Ojciec' i 'Syn' wpisujących się w domenę //przedstawiciele narodu// - reprezentują one już nie tylko relacje rodzinne, ale także dwa pokolenia Polaków, „starych” i „młodych”, symbolizujących sprzeczne wartości, dążenia i ideały. W typowym kontekście przekłada się to na ich stereotypową strukturę semiczną:

Ojciec' => /dojrzałość/, /tradycja/, /przeszłość/, /zakorzenienie/, /fundament/, /szacunek/, /pozytywny/

‘Syn’=> /młodość/, /odnowa/, /przyszłość/, /nadzieja/, /kontynuacja/, /pozytywny/.

$\mathrm{Na}$ planie syntagmatycznym tekstu konfiguracje takie powtarzają się, tworząc odpowiadające wymienionym semom wiązki izotopiczne o spójnej waloryzacji pozytywnej (jako że zazwyczaj stare i nowe pokolenie dopełniają się, a młodzi kontynuują dorobek swoich przodków). W Trans-Atlanty$k u$ jednak ta stereotypowa harmonia ulega zaburzeniu, gdyż pomimo bardzo mocno zaznaczonej obecności motywu ‘Ojczyzny’ (rozumianego zarówno w najbardziej tradycyjnych, jak i czysto kontekstowych znaczeniach) wprowadzony zostaje dopełniający go i jednocześnie stający wobec niego w silnej opozycji motyw 'Synczyzny', nie bez powodu wyrażony za pomocą neologizmu o homologicznej strukturze. Ów zabieg wyeksponowania motywu 'Syna' i 'Synczyzny' oraz podniesienia go do tej samej rangi co motyw 'Ojczyzny’ wiąże się z ustanowieniem między nimi symetrycznej opozycji zarówno na poziomie le ks y k l ny m (użycie odpowiednich par leksemów przeciwstawnych), jak i na poziomie tekstow ym (aktualizacja wiązek izotopicznych realizujących te motywy na planie syntagmatycznym). W pierwszym przypadku analiza Trans-Atlantyku pozwala wskazać leksemy Ojciec / Syn i Ojczyzna / Synczyzna oraz ich synonimy kontekstowe wykazane w tabeli (wraz z przykładami zaczerpniętymi z tekstu' ${ }^{9}$ ):

8 Podobnie jak neutralny z definicji semem 'krzesło', należący zazwyczaj do klasy //meble// lub //sprzęty do siedzenia// może zostać nacechowany negatywnie, gdy zostanie użyty w kontekście krzesło elektryczne, wchodząc wtedy w paradygmat //narzędzia służące do zadawania śmierci//.

${ }^{9} \mathrm{Z}$ powodu ograniczonej objętości artykułu niemożliwe jest niestety zacytowanie szerszych fragmentów badanego tekstu Gombrowicza; podane w analizie odnośniki do stron dotyczą wydania z roku 1988. 
Tabela 1. Opozycja Ojciec / Syn i jej realizacja w tekście Trans-Atlantyku

\begin{tabular}{|c|c|c|}
\hline \multicolumn{2}{|c|}{$\begin{array}{c}\text { Leksemy tworzące } \\
\text { opozycję oraz ich } \\
\text { synonimy kontekstowe }\end{array}$} & $\begin{array}{c}\text { Przykłady } \\
\text { użycia } \\
\text { w Trans-Atlantyku }\end{array}$ \\
\hline $\begin{array}{c}\text { Ojciec } \\
\downarrow \\
\text { 'Stary' } \\
\text { 'Starzec } \\
\text { (krwawy)' } \\
\text { 'Tomasz' } \\
\\
\text { 'Tata' } \\
\text { 'stary pryk' } \\
\text { '(zdziecinniały) } \\
\text { Staruszek' } \\
\downarrow \\
\text { Ojczyzna }\end{array}$ & $\begin{array}{c}\text { Syn } \\
\downarrow \\
\text { 'Chłopiec / } \\
\text { Chłopak / } \\
\text { Chłopaczek' } \\
\text { 'Ignac(y)' } \\
\text { 'Młody' } \\
\text { 'Młodzieniec' } \\
\downarrow \\
\text { Synczyzna }\end{array}$ & $\begin{array}{l}\text { I, już na nic nie bacząc, za tym Młodzieńcem pomknął } \\
\text { (s. 44) } \\
\text { Młody z ojcem swoim (bo to ojciec był) przy stoliku } \\
\text { siedzieli i piwo pili (s. 47) } \\
\text { Dopiroż Stary do mnie, że Syna Jedynego do wojska } \\
\text { wyprawia (s. 53) } \\
\text { Nie chcesz czym Innym, czym Nowym stać się? } \\
\text { Chceszże aby wszyscy Chłopcy wasi tylko za Ojcami } \\
\text { wszystko w kółko powtarzali? Oj wypuścić Chłopaków } \\
\text { z ojcowskiej klatki, niechże i do Nieznanego zajrzą! } \\
\text { Chód w stronę Syna mnie kieruje; i tak, ni stąd, ni } \\
\text { zowąd, ja do Syna idę (...). Syn, Syn, do Syna, do Syna! } \\
\text { (s. 75) } \\
\text { Obyż to Synowie wierni Ojcom i Ojczyźnie byli! (s.76) } \\
\text { Daremne wszakże Boga Ojca imię, gdy Syn przede mną, } \\
\text { gdy tylko Syn i nic oprócz Syna! Syn! Syn! Niech zdy- } \\
\text { cha Ojciec. Syn bez Ojca. Syn Samopas, Syn Rozpęta- } \\
\text { ny, to mi dopiero, to rozumiem! (s. 76) } \\
\text { Wiedz, Tomaszu, że ja ciebie zdradzam i Pojedynek ten } \\
\text { bez kul był (...)! Na miłosierdzie Boże, uchodź z Synem } \\
\text { swoim, uchodź, póki czas (s. 88) } \\
\text { (...) on, stary, też do boju staje. Bić się chce z Ojczyzny } \\
\text { wrogiem! (s. 90) } \\
\text { I otóż na szalę nie tylko on Syna swego Najdroższego } \\
\text { rzuca, ale też uczucia swoje, tę Ofiarę Starca ciężką, } \\
\text { krwawą! Ale marna Ofiara jego. (...) Bo on, z pustej lufy } \\
\text { do Puta pukając, pustym stał się, a może zdziecinniałym } \\
\text { Staruszkiem (s. } 90 \text { ) } \\
\text { on tym synobójczym strasznym mordem Staruszka } \\
\text { pustego w sobie zabija, aby Starcem krwawym, Ciężkim } \\
\text { stać się (s. 90) } \\
\text { - Jaki ty sposób na Ignaca masz? Ignac patrzeć na } \\
\text { ciebie nie może. / (...) - Owszem, dosyć mnie lubi! A ja } \\
\text { to sprawię, że Tatę zabije! (...) A gdy tatobójcą starego } \\
\text { pryka swojego się stanie, pewnie Pomocy i Opieki mojej } \\
\text { potrzebował będzie (s. 91) }\end{array}$ \\
\hline
\end{tabular}


Tabela 1. Opozycja Ojciec / Syn... cd.

\begin{tabular}{|c|c|c|}
\hline \multicolumn{2}{|c|}{$\begin{array}{c}\text { Leksemy tworzące } \\
\text { opozycję oraz ich } \\
\text { synonimy kontekstowe }\end{array}$} & $\begin{array}{c}\text { Przykłady } \\
\text { użycia } \\
\text { w Trans-Atlantyku }\end{array}$ \\
\hline $\begin{array}{c}\text { Ojciec } \\
\downarrow \\
\text { 'Stary' } \\
\text { 'Starzec } \\
\text { (krwawy)' } \\
\text { 'Tomasz' } \\
\\
\text { 'Tata' } \\
\text { 'stary pryk' } \\
\text { '(zdziecinniały) } \\
\text { Staruszek' } \\
\downarrow \\
\text { Ojczyzna }\end{array}$ & $\begin{array}{c}\text { Syn } \\
\downarrow \\
\text { 'Chłopiec / } \\
\text { Chłopak / } \\
\text { Chłopaczek' } \\
\text { 'Ignac(y)' } \\
\text { 'Młody' } \\
\text { 'Młodzieniec' } \\
\downarrow \\
\text { Synczyzna }\end{array}$ & $\begin{array}{l}\text { Starego Ignac zamorduje! (s. 91) } \\
\text { A wtenczas on wykrzyknął: - Synczyzna, Synczyzna! } \\
\text { Ja oniemiałem. A on znowu: - Synczyzna, Synczyzna, } \\
\text { Synczyzna! - krzyczał na cały głos, aż imię to dom cały, } \\
\text { zda się, wypełniło, i na Lasy, na Pola uderzyło; i znów } \\
\text { „Synczyzna” krzyczał, jak opętany... (s. 91-92). } \\
\text { Cóż mi stary! Starego zarżnąć, zakatrupić! Starego } \\
\text { gdzie dopaść, zdusić, Starego niechby młody zdusił! } \\
\text { Wiecznież tedy Ojciec Syna będzie rżnąć? Nigdyż Syn } \\
\text { Ojca? (s. 92) } \\
\text { Syn, Syn, Syn! Do syna biec, uciekać chciałem, w Synu } \\
\text { wytchnienie, ukojenie moje! Jak to ja wzdychałem w pod- } \\
\text { ziemiu owym do rumianych świeżych lic jego, do oczów } \\
\text { żywych, błyszczących, do jasnych kędziorów (s. 106) } \\
\text { Lepiej tedy Ignaca, Tomaszowego syna, zabijmy, bo } \\
\text { śmierć, młodzieńcowi temu bez żadnej przyczyny zada- } \\
\text { na, od wszystkich innych będzie okropniejsza (s. 107) } \\
\text { Wówczas do Syna iść postanowiłem. O Syn, Syn, Syn! } \\
\text { (...) może świeżością jego się odświeżę (s. 113) } \\
\text { Z powrotem wszystko po staremu, tak jak było? On więc } \\
\text { znowu przy Panu Ojcu będzie, i dalej za Panem Ojcem } \\
\text { pacierz klepać, Pana Ojca poły się trzymać... (s. 113-114) } \\
\text { (...) niech się staje co Stać się ma, niech się łamie, pęka, } \\
\text { niech się rozwala, rozwala i o Synczyzna Stająca się } \\
\text { Nieznana Synczyzna! } \\
\text { Tomasz na ziemię upadł!... A tu bach, bach, Ignac } \\
\text { z Bachem swoim nadlatuje, o, i bachnie, bachnie w Ojca } \\
\text { swojego on Bachnie, oj, tyż Bachnie, Bachnie.. O Syn, } \\
\text { Syn, Syn! Niech zdycha Ojciec! (...) Niech Syn morduje } \\
\text { Ojca! (s. 119) }\end{array}$ \\
\hline
\end{tabular}

Źródło: opracowanie własne

$\mathrm{Na}$ planie tekstowym sememy odpowiadające obu motywom wchodzą w skład dwóch głównych izotopii, tj. mak ro-i zoto pi i /lojcowski// vs //synowski//, które wywierają kluczowy wpływ na tematykę całego dzieła 
i wokół których organizują się inne izotopie (o charakterze bardziej podrzędnym i/lub lokalnym), tworząc specyficzne dla Trans-Atlantyku wiązki tematyczne ${ }^{10}$.

W przypadku makro-izotopii //ojcowski//, pomimo zachowania typowych pozytywnych cech semantycznych związanych z ideą Ojca jako ,przodka” czy też „ojca narodu” (/tradycja/, /przeszłość/, /zakorzenienie/, /fundament/, /szacunek/ itd.), w Trans-Atlantyku pojawia się cały wachlarz n e g a ty w ny ch cech kontekstowych przypisanych motywowi 'Ojca' (/słabość/, /niemoc/, /dekadencja/, /starość/, /zdziecinnienie/, /pustka/, /egzaltacja/ itd.), które odnoszą się nie tyle do zalet dojrzałego wieku (mądrość, doświadczenie życiowe, stateczność), co do ułomności związanych ze starością (fizyczna niemoc, otępiałość umysłu, zdziecinnienie, pusta egzaltacja, śmieszny upór w przywiązaniu do tradycji). Wpływa to w nieunikniony sposób na negatywne wartościowanie całej makro-izotopii //ojcowski//, która stanowi jeden z filarów tematycznych tekstu i prowadzi do odmalowania w nim negatywnego wizerunku 'Ojca' i ‘Ojczyzny'. Istotną rolę pełni tu bardzo silnie zaznaczona w tekście izotopia //egzaltacji// (realizowana m.in. za pomocą notorycznego nadużywania wielkiej litery), która odpowiada za groteskowy efekt powieści i odnosi się bezpośrednio do przesadnie wzniosłej, ,pustej” postawy względem Ojczyzny przybieranej na pokaz przez Polaków przebywających na emigracji w Argentynie. Semantycznie //egzaltacja// wchodzi bowiem w tę samą wiązkę izotopiczną co //ojcowski//, potęgując negatywne nacechowanie motywu 'Ojczyzny' w Trans-Atlantyku.

Z kolei motyw 'Syna', pozbawiony tej ,pustej” emfazy, symbolizuje spontaniczne odejście od patriotyzmu i pełną, absolutną wolność związaną z pięknem, czystością i niekontrolowanym élan vital właściwym młodości. Wiązka izotopiczna, która realizuje motyw 'Syna' i 'Synczyzny' na poziomie mikro-semantycznym, obejmuje - obok makro-izotopii //synowski// - izotopie oparte na rekurencji semów /młodość/, /przyszłość/, /spokój/, /wolność/, /brak kontroli/, /czystość/, /piękno/, /spełnienie/, /świeżość/, /nowość/, /tworzenie/ itd. Powiązana na przestrzeni całego tekstu z makro-izotopią //ojcowski// po-

10 Podkreślmy, iż sememy tworzące poszczególne izotopie należy rozpatrywać zarówno w wymiarze paradygmatycznym (przynależność do tych samych klas kontekstowych), jak i syntagmatycznym (efekty sensu wynikające m.in. z powtórzeń typu: A wtenczas on wykrzyknąt: - Synczyzna, Synczyzna! Ja oniemiałem. A on znowu: - Synczyzna, Synczyzna, Synczyzna!). 
zwala ona na aktualizację opozycji kluczowych dla konstrukcji tematycznej całego utworu; są to nie tylko tradycyjne, ,przewidywalne” opozycje /starość/ vs /młodość/, /przeszłość/ vs /przyszłość/, /tradycja/ vs /rewolucja/, ale również kontekstowe konstrukcje semantyczne charakterystyczne tylko dla tekstu Gombrowicza, w szczególności /pustka/ vs /pełnia/, a także/statyczny/ vs /dynamiczny/.

Obydwie wiązki izotopiczne niosą ze sobą ładunek emocjonalno-ewaluacyjny, co wpływa na skojarzenie z nimi odpowiednich izotopii wartościujących. O ile w przypadku motywu 'Syna' zachowane zostaje nacechowanie pozytywne, o tyle kontekstowe wartościowanie sememów związanych z motywem 'Ojca' jest bardziej złożone i skłania się raczej w stronę nacechowania negatywnego. W przybliżeniu (po odjęciu mniej istotnych wariantów kontekstowych specyficznych dla każdego użycia) strukturę sememów 'Ojciec' i ‘Syn’ można przedstawić następująco:

Tabela 2. Mikrostruktura semiczna sememów 'Ojciec' i 'Syn'

\begin{tabular}{|c|c|c|}
\hline & 'Ojciec' ('Ojczyzna') & 'Syn' ('Synczyzna') \\
\hline \multirow{2}{*}{$\begin{array}{c}\text { poziom makrogeneryczny } \\
\text { (wymiar semantyczny) }\end{array}$} & \multicolumn{2}{|c|}{ /ludzki/ SMacroG } \\
\hline & /negatywny/ SMakroGW & /pozytywny/ SMakroGW \\
\hline $\begin{array}{l}\text { poziom mezogeneryczny } \\
\text { (dziedzina semantyczna) }\end{array}$ & \multicolumn{2}{|c|}{ /narodowy/ SMezoG } \\
\hline $\begin{array}{c}\text { poziom mikrogeneryczny } \\
\text { (taksem) }\end{array}$ & \multicolumn{2}{|c|}{ /przedstawiciele narodu/ SMikroG } \\
\hline semy specyficzne & $\begin{array}{c}\text { /stary/ SSA } \\
\text { /przeszłość/, /schyłek/ SSA } \\
\text { /niemoc/, /bezsilność/ SSA } \\
\text { /pustka/ SSA } \\
\text { /egzaltacja/ SSA }\end{array}$ & $\begin{array}{c}\text { /młody/ SSI } \\
\text { /wolność/ SSA } \\
\text { /przyszłość/ SSA } \\
\text { /czystość/ SSA /piękno/ } \\
\text { SSA } \\
\text { /pełnia/, /satysfakcja/ SSA } \\
\text { /brak kontroli/ SSA }\end{array}$ \\
\hline \multicolumn{3}{|c|}{$\begin{array}{l}\text { Skróty: SMakroGW : sem makrogeneryczny wartościujący; } \\
\text { SMezoG : sem mezogeneryczny ; SMikroG : sem mikrogeneryczny; } \\
\text { SSI : sem specyficzny inherentny ; SSA : sem specyficzny aferentny }\end{array}$} \\
\hline
\end{tabular}

Źródło: opracowanie własne 
Przekładają się one na planie syntagmatycznym na odpowiadające poszczególnym semom izotopie, które zostają rozwinięte na przestrzeni całego tekstu lub jego sekwencji. Powstała w ten sposób silna opozycja wartości przypisanych na poziomie tekstu motywom 'Ojca/Ojczyzny' i 'Syna/Synczyzny' determinuje nacechowanie innych sememów wchodzących w te same wiązki izotopiczne i prowadzi do uspójnienia tekstu na planie makrogenerycznym.

\section{Podsumowanie}

Mimo że powyższa analiza nie może być w żadnym razie uznana za wyczerpującą ${ }^{11}$, zarysowuje ona podstawowe relacje semantyczne, jakie nawiązują się pomiędzy sememami 'Ojciec/Ojczyzna' i 'Syn/Synczyzna' w powieści Gombrowicza. Sprzeczność, która pojawia się na poziomie treści ewaluacyjnych postrzeganych w języku (semem-typ 'Ojciec') i w kontekście (sememy-użycia wpisujące się w makro-izotopię /lojcowski//), wydaje się jednym z głównych filarów, na których opiera się efekt szokującego przesłania Trans-Atlantyku. Jako że waga tej opozycji w strukturze całego tekstu nie budzi wątpliwości, jej wpływ na inne aspekty semantyczne dzieła jest znaczący, zaś dysonans wynikający ze sprzecznego wartościowania sememu 'Ojciec' gra istotną rolę w procesie konstruowania świata przedstawionego poprzez dekonstrukcję ogólnie uznanych stereotypów narodowych.

11 Osobnemu rozwinięciu mogłaby zostać poddana na przykład interesująca kwestia relacji kontekstowej zachodzącej w powieści pomiędzy sememem 'Ojciec' +/ludzki/ (Tomasz, przedstawiciel Ojczyzny i ojciec Ignacego) oraz 'Ojciec' +/boski/ (Bóg Ojciec), jak również relacji między sememem ‘Ojciec' (Tomasz / Bóg) et 'Syn’ w kontekście silnie zaznaczonej w tekście opozycji /grzech/ vs /nie-grzech/. W tekście Gombrowicza grzech Syna przeciwko Ojcu jest co prawda zdradą, ale jest to zdrada o nacechowaniu pozytywnym, gdyż ma na celu wyzwolenie siebie, a co za tym idzie wyzwolenie całego narodu z jarzma zbyt radykalnie pojętego patriotyzmu. Wprowadzenie wymiaru nadprzyrodzonego i aluzji do moralności chrześcijańskiej są nie bez znaczenia w ekonomii semantycznej tekstu. 


\section{Bibliografia}

Arrivé M., 1973, Pour une théorie des textes polyisotopiques, Langages 31, s. 53-63.

BARTMIŃSKi J. (red.), 2003, Język w kręgu wartości, Lublin: Wydawnictwo UMCS.

Benveniste E., 1966, Problèmes de linguistique générale, Paris: Gallimard.

Berrendonner A., 1976, De quelques aspects logiques de l'isotopie, Linguistique et sémiologie, I, s. 117-135.

Blumenthal, P., Novakova, I., Siepmann, D. (red.), 2014, Les émotions dans le discours. Emotions in Discourse, Frankfurt am Main: Peter Lang.

Carlos J., Pérennec M.-H. (red.), 2012, Langue et manipulation, Saint-Etienne: Publications de l'Université de Saint-Etienne.

Charaudeau P., Maingueneau D., 2002, Dictionnaire d'analyse du discours, Paris: Seuil.

Cusimano Ch., 2015, Le sens en mouvement. Etudes de sémantique interprétative, Frankfurt am Main: Peter Lang.

Galatanu O., 2007, Sémantique des possibles argumentatifs et axiologisation discursive, w : D. Bouchard, J. Evrard (red.), Représentation du Sens linguistique II, Louvain-la-Neuve: De Boeck/Duculot, s. 313-325.

Gombrowicz W., 1988a, Trans-Atlantyk, Kraków: Wydawnictwo Literackie.

Gombrowicz W., 1988b, Przedmowa do Trans-Atlantyku [1957], w: Trans-Atlantyk, Kraków: Wydawnictwo Literackie, s. 5-7.

Greimas A. J., 1966, Sémantique structurale, Paris: Larousse.

Groupe $\mu, 1990$, Rhétorique de la poésie, Paris: Seuil.

JACKIEWICZ A., 2014, Études sur l'évaluation axiologique : présentation, Langue française, nr 184, 2014/4, s. 5-16.

Jelenski C., 1976, Préface à W. Gombrowicz, Trans-Atlantique, Paris: Denoël, s. 7-22.

Kerbrat-Orecchioni C., 1976, Problématique de l'isotopie, Linguistique et sémiologie, I, s. 11-33.

Kerbrat-Orecchioni C., 1979, De la sémantique lexicale à la sémantique de l'énonciation, Thèse de Doctorat d'État, Lille: Service de reproduction des thèses.

Kerbrat-Orecchioni C., 1980, L'énonciation. De la subjectivité dans le langage, Paris: Armand Colin.

Krzyżanowska A., 2011, Aspects lexicaux et sémantiques de la description des noms d'affect en francais et en polonais, Lublin: Wydawnictwo UMCS.

Krzyżanowska A., WoŁowska K. (red.), 2016a, Les émotions et les valeurs dans la communication I. Découvrir l'univers de la langue, Frankfurt am Main: Peter Lang. 
KrzyżanowsKa A., WolowsKa K. (red.), 2016b, Les émotions et les valeurs dans la communication II. Entrer dans l'univers du discours, Frankfurt am Main: Peter Lang.

LASKOwsKa E., 1992, Wartościowanie w języku potocznym, Bydgoszcz: Wydawnictwo WSP.

Legallois D., Lenepveu V., 2014, L'évaluation dans les textes: des relations inter-propositionnelles aux séquences discursives, Langue française, nr 184, 2014/4, s. $17-33$.

Novakova I., Tutin A. (red.), 2009, Le Lexique des émotions, Grenoble: ELLUG.

Novakova I., Sorba J., 2014, L'évaluation à travers les émotions: le cas d'estime et de déception, Langue française, nr 184, 2014/4, s. 75-91.

Plantin C., 2011, Les bonnes raisons des émotions. Principes et méthode pour l'étude du discours " émotionné », Berne: Peter Lang.

Pottier B., 1974, Linguistique générale. Théorie et description, Paris: Klincksieck.

Puzynina J., 1992, Język wartości, Warszawa: Państwowe Wydawnictwo Naukowe.

RAstier F., 1985, L'isotopie sémantique, du mot au texte, L'Information grammaticale, nr 27, s. 33-36.

RASTIER F., 1987, Sémantique interprétative, Paris: PUF.

Rezsohazy R., 2006, Sociologie des valeurs, Paris: Armand Colin.

Słownik Języka Polskiego PWN (SJP), wersja on-line: http://sjp.pwn.pl/.

WoŁowska K., 2016, Les isotopies évaluatives et la valorisation contextuelle des sémèmes 'Père' et 'Fils' dans Trans-Atlantique de Witold Gombrowicz, w: A. Krzyżanowska, K. Wołowska (red.), Les émotions et les valeurs dans la communication, Frankfurt am Main: Peter Lang, s. 81-100.

WoŁowska K., 2017, Normatywne nacechowanie leksemu a jego użycie w kontekście - o izotopiach wartościujących w interpretacji tekstu, w: A. Kiklewicz, J. Piwowar, Wartości i wartościowanie we współczesnej humanistyce. Perspektywa językoznawcza, Olsztyn: Centrum Badań Europy Wschodniej UWM w Olsztynie, s. $177-187$.

\section{Valuation of the motif of 'Ojczyzna' and 'Synczyzna' in Trans-Atlantic by Witold Gombrowicz in the light of the methodology of interpretative semantics}

\section{( summary)}

The objective of the paper is to analyze the contextual valuation of the sememes 'Father' and 'Son' in Witold Gombrowicz's Trans-Atlantic from a microstructural and interpretative point of view. Since the interpreted semantic content is definitively 
configured only in context, the sememes analyzed here are considered as elements of a whole network of semantico-discursive reports, both paradigmatic (semantic classes) and syntagmatic (isotopies and isotopic beams that can be identified at the level local than global). The value attributed to the sememes 'Father' and 'Son' results here from the interrelation of different elements of the context that challenge the normative evaluation content (for the sememe-type) and introduce semantic opposition in the texte to achieve an expected artistic effect. 